\title{
FAKTOR-FAKTOR YANG MEMPENGARUHI TINGKAT BAGI HASIL DEPOSITO MUDHARABAH PADA BMT MASLAHAH SE-KABUPATEN SITUBONDO
}

\author{
Yulinartati ${ }^{1}$ \\ Email:yulinartati@yahoo.co.id \\ Diyah Probowulan ${ }^{2}$ \\ Email: diyah.probowulan@gmail.com \\ Tara Ayu Adevia Putri ${ }^{3}$ \\ Email: taraayu.ayu07@gmail.com
}

\begin{abstract}
The level of profit sharing provided by Islamic banks is one of the public's attractions to store funds in Islamic banks, but at the profit sharing level. Because it still refers to conventional bank interest rates, people still think that Islamic banks are the same as conventional banks. This study aims to analyze the factors that influence the level of profit sharing of mudharabah deposits at BMT Maslahah in Situbondo Regency. The population used is the annual financial statements in the 5 Sub-District Regencies of Situbondo 2014-2019. The sample selection tested in this study used SPSS 20.0 software. Variables used in this study are Return on Assets (ROA), Capital Adequacy Ratio (CAR), Non Performing Financing (NPF), Financing to Deposits Ratio (FDR), BOPO (Operational Costs Operating Income). As an independent variable, and the level of profit sharing of mudharabah deposits as the dependent variable. Some of the results show that the Return on Assets (ROA), Financing to Deposits Ratio (FDR) have a positive effect on the profit sharing rate of mudharabah deposits while Capital Adequacy Ratio (CAR), Non Performing Financing (NPF), BOPO (Operational Cost of Operating Income) has a negative effect.
\end{abstract}

Keywords: Return on Assets (ROA), Capital Adequacy Ratio (CAR), Non Performing Financing (NPF), Financing to Deposits Ratio (FDR), BOPO (Operational Costs, Operating Income, Profit Sharing Rate for Mudharabah Deposits).

\footnotetext{
1,2 Jurusan Akutansi Fakultas Ekonomi Universitas Muhammadiyah Jember, Jl. Karimata No. 49 Jember 68121

${ }^{3}$ Corresponding Author: Jurusan Akutansi Fakultas Ekonomi Universitas Muhammadiyah Jember, Jl. Karimata No. 49 Jember 68121
} 


\section{PENDAHULUAN}

Paradigma baru dalam sistem ekonomi akhir- akhir ini sering menjadi buah bibir oleh kalangan ekonom, baik dari akademikus atau akademisi maupun praktisi. Munculnya suatu konsep baru yang belum dapat diterima oleh masyarakat, karena belum ada penyaluran pemahaman dari suatu konsep tersebut. Salah konsep yang sering dibicarakan ini adalah konsep mengenai perbankan dan lembaga keuangan syri'ah Islam. Konsep tersebut menerapkan prinsip - prinsip syari'ah Islam kedalam transaksi perbankan. Prinsip utama yang diterapkan yaitu pada transaksi keuangan, yang berupa penyimpanan maupun penyaluran dana yang tidak dikenakan bunga (interest free banking) (Khairunnisa dan Arief Ramelan Karseno 2001, 129). Berdirinya BMT dapat menjadi jalan tengah bagi permasalahan perekonomian pedesaan yang masih rendah. Oleh karena itu BMT masuk untuk memberikan solusi oleh masalah tersebut. Wujud nyatanya adalah dengan memperbanyak pengoprasian lembaga keuangan berprinsip bagi hasil yaitu Baitul Mal wa Tamwil (BMT). Hal tersebut merupakan lembaga keuangan yang kegiatan utamanya mengumpulkan dana masyarakat dalam bentuk tabungan (simpanan) maupun deposito dan menyalurkan kembali kepada masyarakat dalam bentuk pembiayaan, yang berdasarkan prinsip syari'ah melalui mekanisme yang wajar dalam dunia perbankan.

Salah satu lembaga keuangan syariah yang mengalami perkembangan yang cukup pesat saat ini adalah BMT (Baitul mal wa Tamwil). Dimana peran umum BMT adalah melakukan pembinaan dan pendanaan berdasarkan sistem syari'ah. Peran ini menegaskan arti pentingnya prinsip-prinsip syari'ah dalam kehidupan ekonomi masyarakat sebagai lembaga keuangan syariah dalam kehidupan ekonomi masyarakat sebagai lembaga tersebut yang berinteraksi langsung dengan kehidupan masyarakat kecil, maka BMT mempunyai tugas penting dalam pengembangan misi Islaman dengan segala bagian kehidupan masyarakat. Pada proses yang berjalan BMT tetap memberikan pelayanan kepada anggota yang berpenghasilan dua puluh ribu rupiah per harinya sekalipun untuk keperluan produktif maupun konsumtif. Dimana deposito merupakan produk yang berpotensi untuk keseimbangan keuangan bank maupun BMT, karena produk ini melibatkan tuga pihak yang sedang bergerak mengelola sector usaha yang tidak diragukan memberikan nilai tambah pada gerakan ekonomi secar langsung. Oleh karena itu, produk ini mendorong sector riil untuk berkembang (Adnan 2005, 19). Bagi hasil deposito berdasarkan pada prinsip mudharabah. Pada BMT Maslahah Se- Kabupaten Situbondo ini memiliki produk yang bernama deposito yang berdasarkan pada prinsip mudharabah, dimana deposito mudharabah merupakan deposito yang dananya berasal dari pihak ketiga yang kemudian dikelola oleh pihak BMT untuk disalurkan melalui pembiayaan. Keuntungan atau bagi hasil dibagi berdasarkan nisbah yang telah disepakati. Chalifah dan Sodiq (2015) dengan pokok masalah yang dirumuskan adalah pengaruh Return on Asset (ROA), terhadap Profitabilitas Deposito Mudharbah pada Bank Syariah. Mudharabah berpengaruh positif dan terhadap ROA. Hal ini diketahui dari nilai uji $t(8,679)$ lebih dari t tabel $(2,0345)$, dan variable pendapatan musyarakah memiliki efek negatif yangsignifkan terhadap variable ROA. Hal ini diketahui dari nilai uji t $(-4,905)$ lebih kecil dari tabel t $(2,0345)$. Kemudian, secara simultan keua kontrak berpengaruh positif terhadap ROA hal itu diketahui dari nilai uji F $(46,383)$ lebih dari F tabel (3.28).

Diyanto dan Savitri (2015), melakukan penelitian tentang faktor-faktor yang mempengaruhi pertumbuhan deposito mudharabah pada Bank Syariah. Pada penelitian ini, pengujian dilakukan dengan analisis regresi linier berganda, yaitu suatu 
metode yang umum digunakan untuk meneliti hubungan antara sebuah variable dependen dengan beberapa variable independen. Berdasarkan hasil penelitian dan pembahasan, dapat disimpulkan bahwa : 1). Tingkat suku bunga BI bepengaruh terhadap deposito mudharabah. 2). Tingkat bagi hasil berpengauh signifkan terhadap variable deposito mudharabah. 3). FDR berpengaruh terhadap variable deposito mudharabah. 4). Koefisien determinasi yang diperoleh sebesar 0,441 atau 44,1\% yang berarti $44,1 \%$ penyebab variasi pada Deposito Mudharabah adalah perubahan Tingkat Suku Bunga BI, Tingkat Bagi Hasil, dan FDR yang terjadi pada secara bersama-sama.

Sabtatianto dan Yusuf (2018), menganalisis faktor-faktor yang mempengaruhi tingat bagi hasil deposito mudharabah. Proksi profitabilitas yang digunakan adalah ROA (Mas'ud et al. 2020). Hasil Penelitian menunjukkan bahwa terdapat lima variable yaitu ROA, CAR, FDR, NPF, dan BOPO. Dimana FDR memiliki pengaruh positif terhadap tingkat bagi hasil deposito muharabah, sedangkan ROA, CAR, NPF, dan BOPO memiliki pengaruh negatif terhadap tingkat bagi hasil deposito mudharabah.

Novianti et al. (2015), melakukan penelitian tentang analisis pengaruh Return on Asset (ROA), BOPO, Suku Bunga, Financing To Deposits Ratio (FDR) dan Non Performing Financing (NPF) terhadap tingkat bagi hasil deposito mudharabah. Hasil penelitian menunjukkan ROA dan FDR berpengaruh positif terhadap tingkat bagi hasil deposito muharabah sedangkan BOPO, Suku Bunga, NPF tidak berpengaruh terhadap tingkat bagi hasil deposito mudharabah.

Rahayu (2015), melakukan penelitian tentang Pengaruh Return on Asset, BOPO, Suku Bunga dan Capital Adequacy Ratio terhadap Tingkat Bagi Hasil Deposito Mudharabah Pada Perbankan Syariah. Hasil penelitian menunjukkan ROA, BOPO, Suku Bunga, dan CAR berpengaruh positif terhadap tingkat bagi hasil deposito mudharabah.

Hasil penelitian dari Umiyati dan Syarif (2016) menunjukkah bahwa Laba operasional digunakan untuk pengukuran kinerja ini karena semakin tinggi laba operasional maka semakin bertambah pendapaan perusahaan. Jadi laba operasional berpengaruh positif terhadap tingkat bagi hasil deposito mudharabah.

\section{LANDASAN TEORI DAN PENGEMBANGAN HIPOTESIS 2.1 Financing Deposits Ratio (FDR)}

Rasio Financing to Deposits Ratio (FDR), adalah rasio kredit yang diberikan kepada pihak ketiga dalam rupiah dan valuta asing, tidak termasuk kredit terhadap bank lain, terhadap dana pihak ketiga yang mencangkup giro, tabungan dan deposito dalam rupiah dan valuta asing, tidak termasuk dana antarbank dengan formula sebagai berikut (IBI 2014, 287):

$$
F D R=\frac{\text { Jumlah Pembiayaan yang Diberikan }}{\text { Jumlah Dana yang Diterima oleh Bank }} \times 100 \%
$$

\subsection{Return on Assets (ROA)}

Return on asset (ROA) merupakan bagian dari rasio profitabilitas yang digunakan Rasio ini Rasio ini digunakan untuk mengukur kemampuan manajemen

$$
\mathrm{ROA}=\frac{\text { Laba Bersih setelah pajak }}{\text { Total Aktiva }} \times 100 \%
$$


bank dalam memperoleh keuntungan (laba sebelum pajak) yang dihasilkan dari ratarata total aset bank yang bersangkutan. Menurut Lukman $(2009,118)$, return on asset (ROA) adalah rasio yang digunakan untuk mengukur kemampuan manajemen bank dalam memperoleh keuntungan (laba) secara keseluruhan. Semakin besar ROA suatu bank, semakin besar pula tingkat keuntungan. Rumus menghitung ROA:

\subsection{Capital Adequacy Ratio (CAR)}

Capital Adequacy Ratio (CAR) adalah rasio yang memperlihatkan seberapa jauh seluruh aktiva BMT yang mengandung resiko, ikut dibiyai dari modal sendiri BMT disamping memperoleh dana-dana dari sumber-sumber diluar BMT.

$$
C A R=\frac{\text { Modal }}{\text { ATMR }} \times 100 \%
$$

\subsection{Non Performing Financing (NPF)}

Non Perorming Financing (NPF) adalah kredit bermasalah yang terdiri dari kredit yang berklasifikasi kredit kurang lancar, kredit diragukan dan kredit macet.

$$
C A R=\frac{\text { Jumlah Pembiayaan Bermasalah }}{\text { Total Pembiayaan }} \times 100 \%
$$

\subsection{Biaya Operasional per Pendapatan Operasional (BOPO)}

BOPO merupakan rasio perbandingan antara total beban operasional terhadap pendapatan operasional (IBI 2014, 287). Rasio BOPO digunakan untuk mengukur tingkat efisiensi dan kemampuan bank dalam melakukan kegiatan operasinya. Semakin tinggi rasio ini menunjukkan semakin tidak efisien operasional bank (Taswan 2010, 167). Rumus yang digunakan untuk mencari BOPO adalah:

$$
\text { BOPO }=\frac{\text { Total Beban Operasional }}{\text { Total Pendapatan Operasional }} \times 100 \%
$$

\subsection{Laba Operasional}

Laba Operasional merupakan kelebihan total pendapatan dibandingkan total bebannya, disebut juga pendapatan bersih atau net earnings (Horngren et al. 2002). Sedangkan menurut pandangan Islam Laba Operasional secara bahasa atau menurut Al- Qur'an, As- Sunnah, dan pendapat ulama-ulama fiqih dapat disimpulkkan bahwa laba ialah pertambahan pada modal pokok perdagangan atau dapat juga dikatakan sebagai tambahan nilai yang timbul karena barter atau ekspedisi barang dagang. Rumus yang digunakan unuk mencari laba operasional adalah:

Laba Operasional $=$ Total Pendapatan Operasional - Total Beban Operasional

\subsection{Pengaruh Financing Deposit Ratio (FDR) terhadap Bagi Hasil Deposito}

Nisbah at-Tamwil al- Wada'I atau disebut dengan Financing to Deposit Ratio (FDR) yaitu rasio pembiayaan koperasi syariah dengan dana pihak ketiga , jadi perbandingan antara seluruh jumlah pembiayaan yang diberikan bank dengan dana yang diterima bank.jumlah pembiayaan yang diberikan bank antara lain bunga deposito, bungan tabungan, bunga investasi sedangkan dana yang diterima bank yaitu deposito, tabungan, dan investasi. Sehingga semakin tinggi rasio FDR maka bank tersebut akan meningkatkan perolehan dananya, salah satunya dari sisi deposito, dan untuk menarik investor menginvestasikan dananya di koperasi syari'ah, maka diberikanlah tingkat bagi hasil yang menarik sehingga peningkatan FDR akan 
meningkatkan return bagi hasil mudharabah Dari uraian diatas maka dapat hipotesis yang terbentuk adalah sebagai berikut:

H1: $\quad$ Financing Deposit Ratio (FDR) Berpengaruh Positif terhadap Bagi Hasil Deposito

\subsection{Pengaruh Return on Assets (ROA) terhadap Bagi Hasil Deposito}

Berdasarkan hasil analisis ada pengaruh positif yang antara Return on Asset terhadap tingkat bagi hasil deposito Mudharabah hal ini dibuktikan sign $<\alpha=0,05$ demikian H1 diterima. Hal ini berarti hipotesis yang menyatakan bahwa Return on Asset berpengaruh positif terhadap tingkat bagi hasil deposito Mudharabah dapat diterima. Dari uraian diatas maka dapat hipotesis yang terbentuk adalah sebagai berikut:

H2: Return on Assets (ROA) Berpengaruh Positif terhadap Bagi Hasil

Deposito

\subsection{Pengaruh Capital Adequacy Ratio (CAR) terhadap Bagi Hasil Deposito}

Berdasarkan hasil analisis tidak ada pengaruh yang siginifikan anatar capital adequacy ratio terhadap tingkat bagi hasil deposito mudharabah hal ini dibuktikan sign $>\alpha=0,05$ demikian H3 ditolak. Semakin besar CAR maka tingkat bagi hasil deposito mudharabah yang diperoleh bank akan semakin besar karena semakin besar CAR maka semakin tinggi kemampuan permodalan bank dalam menjaga kemungkinan timbulnya resiko kerugian kegiatan usahanya, namun belum tentu secara nyata berpengaruh terhadap peningkatan tingkat bagi hasil deposito mudahrabah. Dari uraian diatas maka dapat hipotesis yang terbentuk adalah sebagai berikut:

\section{H3: Capital Adequacy Ratio (CAR) Berpengaruh Positif Terhadap Bagi Hasil Deposito}

\subsection{Pengaruh Non Performing Financing (NPF) terhadap Bagi Hasil Deposito}

Hal ini dibuktikan dengan besarnya koefisien regresi sebesar 0,30 dan tingkat sinya sebesar 0,074 lebih besar dari n ilai yaitu 5\%. Hal ini mengidikasikan bahwa NPF bukan fsktor utama yang mempengaruhi tingkat bagi hasil. Hasil tersebut menunjukkan bahwa NPF tidak berpengaruh terhadap tingkat bagi hasil deposito mudharabah atau dengan kata lain hipotesis 4 (H4) ditolak. Dari uraian diatas maka dapat hipotesis yang terbentuk adalah sebagai berikut:

H4: $\quad$ Non Performing Financing (NPF) Berpengaruh Negatif terhadap Bagi Hasil Deposito

\subsection{Pengaruh Biaya Operasional per Pendapatan Operasional (BOPO) terhadap Bagi Hasil Deposito}

Hal ini dibuktikan dengan besarnya koefisien regresi sebersar 0,251 dan tingkat sinya sebesar 0,204 lebih besar dari nilai sinya yaitu 5\%. Hasil tersebut menunjukkan bahwa BOPO tidak berpengaruh terhadap tingkat bagi hasil deposito mudharabah atau dengan kata lain hipotesis 5 (H5) ditolak. Dari uraian diatas maka dapat hipotesis yang terbentuk adalah sebagai berikut:

H5: Biaya Operasional per Pendapatan Operasional (BOPO) Berpengaruh

Negatif terhadap Bagi Hasil Deposito 


\subsection{Pengaruh Laba Operasional terhadap Bagi Hasil Deposito}

Berdasarkan hasil penelitian dalam analisis dari suatu jurnal tersebut terdapat pengaruh positif hal ini dibuktikan sign $<\alpha=0,05$ demikian $\mathrm{H} 1$ diterima. Hal ini berarti hipotesis yang menyatakan bahwa laba operasional berpengaruh positif terhadap tingkat bagi hasil deposito mudharabah. Dari uraian diatas maka dapat hipotesis yang terbentuk adalah sebagai berikut:

H6: Laba Operasional Berpengaruh Positif terhadap Bagi Hasil Deposito

\section{METODE PENELITIAN}

\subsection{Jenis, Sifat, Populasi, dan Sampel Penelitian}

Jenis penelitian ini termasuk dalam jenis penelitian terapan (appliend research), merupakan tipe penelitian yang menekan pada pemecahan masalahmasalah praktis. Penelitian ini diarahkan untuk menjawab pertanyaan spesifik dalam rangka penentuan kebijakan, tindakan atau kinerja tertentu (Indriantoro dan Supomo 2009, 147). Penelitian ini juga bersifat kuantitaf karena data yang digunakan merupakan angka atau besaran tertentu yang bersifat pasti. Data kuantitatif bisa dianalisis dengan menggunakan pendekatan statistik.

Populasi merupakan keseluruhan objek atau subjek yang berada pada suatu wilayah dan memenuhi syarat-syarat tertentu yang berkaitan dengan masalah penelitian, atau keseluruhan capem atau individu dalam ruang lingkup yang akan diteliti. Populasi dalam penelitian ini adalah laporan keuangan pada BMT Maslahah Se-kabupaten Situbondo.

Sampel merupakan bagian dari populasi yang memilki ciri-ciri atau keadaan tertentu yang akan diteliti. Sampel dalam penelitian ini adalah data yang diambil dari laporan keuangan BMT Maslahah pada tahun 2014-2019 teknik pengambilan sampel yang digunakan dalam penelitian ini adalah purposive sampling, yaitu pengambilan sampel berdasarkan laporan keuangan tahun 2014-2019. Pada penelitian BMT Maslahah Se-kabupaten Situbondo peneliti mengambil lima capem pada Kabupaten Situbondo diantaranya, Capem Suboh, Capem Mandingan, Capem Bungatan, Capem Olean, Capem Mangaran. Dari ke-lima capem tersebut akan diteliti dari laporan keuangan tahunan pada lima tahun terakhir.

\subsection{Metode dan Teknik Pengumpulan Data}

Uji yang akan dilakukan adalah uji asumsi klasik dan uji hipotesis. Uji asumsi klasik digunakan untuk menguji apakah data yang digunakan merupakan data linier terbaik (best linier unbiased/BLUE). Sedangkan uji hipotesis dilakukan untuk menguji kebenaran hipotesis berdasarkan data penelitian. Persamaan regresi yang dibentuk adalah sebagai berikut (Algifari 2003, 223).

$\begin{array}{ccl}\text { Dimana } \mathrm{Y}=\mathrm{a}+\mathrm{b}_{1 \times 1}-\mathrm{b}_{2 \times 2}-\mathrm{b}_{3 \times 3}-\mathrm{b}_{4 \times 4}-\mathrm{b}_{5 \times 5}-\mathrm{b}_{6 \times 6}+\mathrm{e} \\ \mathrm{Y} & =\text { Tingkat bagi hasil deposito mudharabah } \\ \mathrm{a} & =\text { konstanta } \\ \mathrm{b}_{1}-\mathrm{b}_{3} & =\text { koef isie`n regresi masing-masing } \\ \mathrm{x}_{1} & =\text { financing deposit ratio }(\mathrm{FDR}) \\ \mathrm{x}_{2} & =\text { return on asset }(\mathrm{ROA}) \\ \mathrm{x}_{3} & =\text { capital adequacy ratio }(\mathrm{CAR}) \\ \mathrm{x}_{4} & =\text { non performing financing }(\mathrm{NPF}) \\ \mathrm{x}_{5} & =\text { biaya operasional terhadap pendapatan } \\ & \text { operasional }(\mathrm{BOPO})\end{array}$




$$
\begin{array}{ll}
\mathrm{X}_{6} & =\text { Laba Operasional } \\
\mathrm{e} & =\text { variable gangguan }
\end{array}
$$

Penggunaan uji asumsi klasik dilakukan agar memperoleh hasil regresi yang bisa dipertanggunugjawabkan dan mempunyai hasil yang tidak bias atau best linier unbiased estimator (BLUE). Uji asumsi klasik meliputi beberapa uji sebagai berikut; uji multikolinearitas dan uji normalitas. Dan pada pengujian hipotesis terdapat uji F, Uji Parsial serta Koefisien Determinasi $\left(\mathrm{R}^{2}\right)$.

\section{HASIL DAN PEMBAHASAN}

4.1 Uji Asumsi Klasik

\subsubsection{Uji Normalitas}

Hasil pengujian normalitas terlihat sebagai berikut:

Tabel 1 Hasil Uji Normalitas

One-Sample Kolmogorov-Smirnov Test

\begin{tabular}{|c|c|c|}
\hline $\mathrm{N}$ & & 30 \\
\hline \multirow[t]{2}{*}{ Normal Parameters ${ }^{\mathrm{a}, \mathrm{b}}$} & Mean & .0000000 \\
\hline & Std. Deviation & .27855393 \\
\hline \multirow[t]{3}{*}{ Most Extreme Differences } & Absolute & .178 \\
\hline & Positive & .178 \\
\hline & Negative & -.133 \\
\hline Test Statistic & & .178 \\
\hline Asymp. Sig. (2-tailed) & & $.916^{\mathrm{c}}$ \\
\hline
\end{tabular}

Unstandardized Residual

Sumber: Lampiran (Data Diolah)

Berdasarkan Tabel 1 dapat diketahui hasil uji normalitas dengan kolmogrov smirnov test terhadap variabel FDR $\left(\mathrm{X}_{1}\right)$, ROA $\left(\mathrm{X}_{2}\right)$, CAR $\left(\mathrm{X}_{3}\right)$, NPF $\left(\mathrm{X}_{4}\right)$, BOPO $\left(\mathrm{X}_{5}\right)$, dan Laba Operasional $\left(\mathrm{X}_{6}\right)$ terhadap TBHM (Y) diperoleh nilai asymp sig atau probabilitas sebesar 0,916 yang lebih dari 0,05 sehingga dapat diartikan bahwa model yang terbentuk terdistribusi normal.

\subsubsection{Uji Multikolinearitas}

Hasil pengujian multikolinearitas terlihat sebagai berikut:

Tabel 2 Hasil Uji Multikolinearitas

\begin{tabular}{lccc}
\hline \multicolumn{1}{c}{ Variabel } & Tolerance & VIF & Keterangan \\
\hline FDR $\left(\mathrm{X}_{1}\right)$ & 0,107 & 4,367 & Tidak terjadi multikolinieritas \\
ROA $\left(\mathrm{X}_{2}\right)$ & 0,238 & 4,208 & Tidak terjadi multikolinieritas \\
CAR $\left(\mathrm{X}_{3}\right)$ & 0,214 & 4,681 & Tidak terjadi multikolinieritas \\
NPF $\left(\mathrm{X}_{4}\right)$ & 0,292 & 3,420 & Tidak terjadi multikolinieritas \\
BOPO $\left(\mathrm{X}_{5}\right)$ & 0,130 & 4,688 & Tidak terjadi multikolinieritas \\
Laba Operasional $\left(\mathrm{X}_{6}\right)$ & 0,194 & 4,167 & Tidak terjadi multikolinieritas \\
\hline
\end{tabular}

Sumber: Lampiran (Data Diolah) 
Berdasarkan Tabel 2 dapat diketahui hasil uji multikoliniertas terhadap variabel FDR $\left(\mathrm{X}_{1}\right)$, ROA $\left(\mathrm{X}_{2}\right)$, CAR $\left(\mathrm{X}_{3}\right)$, NPF $\left(\mathrm{X}_{4}\right)$, BOPO $\left(\mathrm{X}_{5}\right)$, dan Laba Operasional $\left(\mathrm{X}_{6}\right)$ menunjukan bahwa masing-masing variabel memiliki nilai tolerance lebih dari 0,1 dan VIF kurang dari 10 sehingga dapat diartikan bahwa tidak terjadi multikolinieirtas terhadap variabel independen dalam penelitian ini.

\subsection{Analisis Regresi Linier Berganda}

Hasil Uji F

Hasil Uji F dapat dilihat pada Tabel 3 berikut ini:

Tabel 3. Hasil Uji F

\begin{tabular}{lrrrrr}
\hline Model & Sum of Squares & \multicolumn{1}{c}{ Df } & Mean Square & \multicolumn{1}{c}{ F } & Sig. \\
\hline 1 Regression & 26.750 & 6 & 4.458 & 45.570 & $.000^{\mathrm{b}}$ \\
Residual & 2.250 & 23 & .098 & & \\
Total & 29.000 & 29 & & & \\
\hline
\end{tabular}

Sumber: Lampiran (Data Diolah)

Berdasarkan Tabel 3 dapat diketahui hasil uji F variabel FDR $\left(\mathrm{X}_{1}\right)$, ROA $\left(\mathrm{X}_{2}\right)$, CAR $\left(\mathrm{X}_{3}\right)$, NPF $\left(\mathrm{X}_{4}\right)$, BOPO $\left(\mathrm{X}_{5}\right)$, dan Laba Operasional $\left(\mathrm{X}_{6}\right)$ dimasukkan dalam model mempunyai pengaruh secara bersama-sama terhadap variabel terhadap TBHM (Y) menunjukan nilai $\mathrm{F}$ hitung sebesar 45,570 yang lebih besar dari $\mathrm{F}$ tabel dengan df1 $=6$ dan df $2=\mathrm{n}-1=29$ sebesar 2,55 dan nilai si sebesar 0,000 yang lebih kecil dari taraf si yang ditentukan yaitu 0,05 sehingga dapat diartikan bahwa variabel FDR $\left(\mathrm{X}_{1}\right)$, ROA $\left(\mathrm{X}_{2}\right)$, CAR $\left(\mathrm{X}_{3}\right)$, NPF $\left(\mathrm{X}_{4}\right)$, BOPO $\left(\mathrm{X}_{5}\right)$, dan Laba Operasional $\left(\mathrm{X}_{6}\right)$ secara simultan berpengaruh terhadap TBHM (Y) pada BMT Maslahah Se-Kabupaten Situbondo.

\subsubsection{Uji Koefisien Determinasi $\left(\mathbf{R}^{2}\right)$}

Uji koefisien determinasi bertujuan untuk mengukur seberapa jauh kemampuan model dalam menerangkan variasi variabel dependen.Hal ini, ditunjukkan oleh besarnya koefisien determinasi $\left(\mathrm{R}^{2}\right)$.Nilai koefisien determinasi antara 0 sampai 1.Besarnya nilai $\mathrm{R}^{2}$ jika semakin mendekati 0 berarti kemampuan variabel-variabel independen dalam menjelaskan variase variabel dependen amat terbatas.Besarnya $\mathrm{R}^{2}$ jika semakin mendekati 1 berati variabel-variabel independen memberikan hampir semua informasi yang dibutuhkan untuk mempredeksi variabel dependen.Hasil uji koefisien determinasi disajikan pada Tabel 4 berikut.

Tabel 4. Hasil Uji Koefieisn Determinasi

\begin{tabular}{lcrcr}
\hline Model & $\boldsymbol{R}$ & $\boldsymbol{R}$ Square & $\begin{array}{c}\text { Adjusted } \boldsymbol{R} \\
\text { Square }\end{array}$ & $\begin{array}{c}\text { Std. Error of the } \\
\text { Estimate }\end{array}$ \\
\hline 1 & $0,960^{\mathrm{a}}$ & 0,922 & 0,902 & 0,31278389 \\
\hline
\end{tabular}

Sumber: hasil olahan data 
Berdasarkan Tabel 4 dapat diketahui hasil uji koefisien determinasi variabel FDR $\left(\mathrm{X}_{1}\right)$, ROA $\left(\mathrm{X}_{2}\right)$, CAR $\left(\mathrm{X}_{3}\right), \mathrm{NPF}\left(\mathrm{X}_{4}\right)$ dan BOPO $\left(\mathrm{X}_{5}\right)$ terhadap TBHM $(\mathrm{Y})$ menunjukan nilai $\mathrm{R}$ Square atau $\mathrm{R}^{2}$ sebesar 0,902 yang menunjukan bahwa variabel FDR $\left(\mathrm{X}_{1}\right)$, ROA $\left(\mathrm{X}_{2}\right)$, CAR $\left(\mathrm{X}_{3}\right)$, NPF $\left(\mathrm{X}_{4}\right)$ dan BOPO $\left(\mathrm{X}_{5}\right)$ berpengaruh terhadap variabel TBHM (Y) sebesar 90,2\% sedangkan sisanya yaitu sebesar 9,8\% dipengaruhi oleh variabel lain yang tidak digunakan dalam model penelitian ini.

\subsubsection{Hasil Uji T}

1. Perumusan Hipotesis

a) $\mathrm{H}_{01}: \beta_{1}=0$ tidak terdapat pengaruh FDR terhadap tingkat bagi hasil Mudharabah pada BMT Maslahah se Kabupaten Situbondo $\mathrm{H}_{\mathrm{a} 1}: \beta_{1} \neq 0$ terdapat pengaruh FDR terhadap tingkat bagi hasil Mudharabah pada BMT Maslahah se Kabupaten Situbondo

b) $\mathrm{H}_{02}: \beta_{1}=0$ tidak terdapat pengaruh ROA terhadap tingkat bagi hasil Mudharabah pada BMT Maslahah se Kabupaten Situbondo $\mathrm{H}_{\mathrm{a} 2}: ß_{1} \neq 0$ terdapat pengaruh ROA terhadap tingkat bagi hasil Mudharabah pada BMT Maslahah se Kabupaten Situbondo

c) $\mathrm{H}_{03}: \beta_{1}=0$ tidak terdapat pengaruh CAR terhadap tingkat bagi hasil Mudharabah pada BMT Maslahah se Kabupaten Situbondo $\mathrm{H}_{\mathrm{a} 3}: \beta_{1} \neq 0$ terdapat pengaruh CAR terhadap tingkat bagi hasil Mudharabah pada BMT Maslahah se Kabupaten Situbondo

d) $\mathrm{H}_{04}: \beta_{1}=0$ tidak terdapat pengaruh NPF terhadap tingkat bagi hasil Mudharabah pada BMT Maslahah se Kabupaten Situbondo $\mathrm{H}_{\mathrm{a} 4}: \beta_{1} \neq 0$ terdapat pengaruh NPF terhadap tingkat bagi hasil Mudharabah pada BMT Maslahah se Kabupaten Situbondo

e) $\mathrm{H}_{05}: \beta_{1}=0$ tidak terdapat pengaruh BOPO terhadap tingkat bagi hasil Mudharabah pada BMT Maslahah se Kabupaten Situbondo $\mathrm{H}_{\mathrm{a} 5}: \beta_{1} \neq 0$ terdapat pengaruh BOPO terhadap tingkat bagi hasil Mudharabah pada BMT Maslahah se Kabupaten Situbondo

f) $\mathrm{H}_{06}: \beta_{1}=0$ tidak terdapat pengaruh Laba Operasional terhadap tingkat bagi hasil Mudharabah pada BMT Maslahah se Kabupaten Situbondo $\mathrm{H}_{\mathrm{a} 6}: \beta_{1} \neq 0$ terdapat pengaruh Laba Operasional terhadap tingkat bagi hasil Mudharabah pada BMT Maslahah se Kabupaten Situbondo

2. Penentuan Taraf Keyakinanan

Taraf keyakinan dalam penelitian ini menggunakan $95 \%$ atau alpha $=5 \%$ dan nilai df $(n-k-1)=24$

3. Penentuan Kriteria Pengujian

$\mathrm{H}_{0}$ diterima apabila $-\mathrm{t}$ tabel $<-\mathrm{t}$ hitung atau $\mathrm{t}$ hitung $>\mathrm{t}$ tabel

$\mathrm{H}_{0}$ ditolak apabila $-\mathrm{t}$ tabel $>-\mathrm{t}$ hitung atau $\mathrm{t}$ hitung $<\mathrm{t}$ tabel

4. Penentuan nilai $t$ tabel

Level of significance $(\alpha)=5 \%$

Degree of Freedom $=(30-6-1)=23$, maka t tabel 0,025;23 $=2,069$

5. Penentuan nilai t hitung 
t hitung diperoleh dari hasil output SPSS yang disajikan pada Tabel 5 berikut:

Tabel 5 Hasil Uji t

\section{Coefficients $^{\mathbf{a}}$}

\begin{tabular}{|c|c|c|c|c|c|c|}
\hline \multirow{2}{*}{\multicolumn{2}{|c|}{ Model }} & \multicolumn{2}{|c|}{$\begin{array}{c}\text { Unstandardized } \\
\text { Coefficients }\end{array}$} & \multirow{2}{*}{$\begin{array}{c}\text { Standardized } \\
\text { Coefficients } \\
\text { Beta }\end{array}$} & \multirow[b]{2}{*}{$t$} & \multirow[b]{2}{*}{ Sig. } \\
\hline & & $B$ & Std. Error & & & \\
\hline \multirow[t]{7}{*}{1} & (Constant) & .079 & .078 & & 1.019 & .319 \\
\hline & $\mathrm{X} 1$ & .596 & .204 & .521 & 2.929 & .008 \\
\hline & $\mathrm{X} 2$ & .215 & .124 & .206 & 1.733 & .097 \\
\hline & X3 & -.301 & .131 & -.289 & -2.297 & .031 \\
\hline & $\mathrm{X} 4$ & -.243 & .107 & -.243 & -2.261 & .034 \\
\hline & X5 & -.572 & .215 & -.428 & -2.660 & .014 \\
\hline & X6 & .355 & .092 & .512 & 3.874 & .001 \\
\hline
\end{tabular}

a. Dependent Variable: $\mathrm{Y}$

6. Membandingkan t hitung dengan $t$ tabel

a) Nilai thitung FDR 2,929 > t tabel 2,069

Karena thitung berada diantara t tabel $-2,069$ dan $+2,069$ maka $\mathrm{H}_{01}$ ditolak

b) Nilai t hitung ROA $1,733<\mathrm{t}$ tabel 2,069

Karena t hitung ROA berada diantara t tabel -2,069 sampai dengan 2,069 maka $\mathrm{H}_{02}$ diterima

c) Nilai t hitung CAR -2,297 < dari t tabel -2,069

Karena $t$ hitung CAR berada diantara $t$ tabel -2,069 dan $+2,069$ maka $\mathrm{H}_{03}$ ditolak

d) Nilai t hitung NPF -2,261 < dari t tabel $-2,069$

Karena t hitung CAR berada diantara t tabel -2,069 dan $+2,069$ maka $\mathrm{H}_{04}$ ditolak

e) Nilai t hitung BOPO - 2,660 < t tabel - 2,069

Karena thitung BOPO berada diantara t tabel -2,069 dan +2,069 maka $\mathrm{H}_{05}$ ditolak

f) Nilai thitung Laba Operasional 3,874 < t tabel 2,069

Karena t hitung ROA berada diantara $t$ tabel -2,069 sampai dengan 2,069 maka $\mathrm{H}_{02}$ diterima

7. Membuat Kesimpulan

a) FDR terhadap TBHM

Berdasarkan hasil pengujian pengaruh antara variabel FDR terhadap TBHM memperoleh $\mathrm{t}$ hitung 2,929 yang lebih besar dari t tabel 2,069 sehingga $\mathrm{H}_{01}$ ditolak $\mathrm{H}_{\mathrm{a}}$ diterima artinya FDR berpengaruh positif terhadap TBHM pada BMT Maslahah se Kabupaten Situbondo.

b) ROA terhadap TBHM

Berdasarkan hasil pengujian pengaruh antara variabel ROA terhadap TBHM memperoleh $t$ hitung 1,733 yang lebih kecil dari t tabel 2,069 
sehingga $\mathrm{H}_{02}$ diterima $\mathrm{H}_{\mathrm{a} 2}$ ditolak artinya ROA tidak berpengaruh positif terhadap TBHM pada BMT Maslahah se Kabupaten Situbondo.

c) CAR terhadap TBHM

Berdasarkan hasil pengujian pengaruh antara variabel CAR terhadap TBHM memperoleh $t$ hitung -2,297 yang lebih kecil dari t tabel -2,069 sehingga $\mathrm{H}_{03}$ ditolak $\mathrm{H}_{\mathrm{a} 3}$ diterima artinya CAR berpengaruh negatif terhadap TBHM pada BMT Maslahah se Kabupaten Situbondo.

d) NPF terhadap TBHM

Berdasarkan hasil pengujian pengaruh antara variabel NPF terhadap TBHM memperoleh t hitung -2,261 yang lebih kecil dari t tabel -2,069 sehingga $\mathrm{H}_{04}$ ditolak $\mathrm{H}_{\mathrm{a} 4}$ diterima artinya NPF berpengaruh negatif terhadap TBHM pada BMT Maslahah se Kabupaten Situbondo.

e) BOPO terhadap TBHM

Berdasarkan hasil pengujian pengaruh antara variabel BOPO terhadap TBHM memperoleh $t$ hitung -2,660 yang lebih kecil dari t tabel -2,069 sehingga $\mathrm{H}_{05}$ ditolak $\mathrm{H}_{\mathrm{a}}$ diterima artinya $\mathrm{BOPO}$ berpengaruh negatif terhadap TBHM pada BMT Maslahah se Kabupaten Situbondo.

f) Laba Operasional terhadap TBHM

Berdasarkan hasil pengujian pengaruh antara variabel Laba Operasional terhadap TBHM memperoleh t hitung 3,874 yang lebih besar dari t tabel 2,069 sehingga H06 ditolak Ha6 diterima artinya Laba Operasional berpengaruh positif terhadap TBHM pada BMT Maslahah se Kabupaten Situbondo.

\subsection{Pembahasan}

\subsubsection{Pengaruh FDR terhadap TBHM pada BMT Maslahah Se-Kabupaten Situbondo}

Pengaruh FDR terhadap tingkat bagi hasil deposito mudharabah menunjukkan hasil bahwa FDR berpengaruh terhadap Tingkat Bagi Hasil Mudharabah pada BMT Maslahah Se-Kabupaten Situbondo ditunjukan dengan nilai t hitung lebih besar dari t tabel (2,929>2,069), artinya bahwa semakin baik financing deposit to ratio pada BMT Maslahah Se-Kabupaten Situbondo maka Tingkat Bagi Hasil Mudharabah pada BMT tersebut akan meningkat.

Semakin banyak dana yang disalurkan oleh pihak BMT Maslahah SeKabupaten Situbondo kepada pembiayaan berarti semakin tinggi earning asetnya sehingg dana yang dihimpun dari masyarakat dapat disalurkan kepada pembiayaan yang produktif (tidak banyak aset yang menganggur). Dengan kata lain, tingginya FDR maka semakin tinggi pula penghasilan yang diperoleh BMT Maslahah SeKabupaten Situbondo sehingga tingkat bagi hasil juga mengalami peningkatan.

Hasil penelitian ini sesuai dengan penelitian yang dilakukan oleh Diyanto dan Savitri (2015) yang membuktikan bahwa FDR berpengaruh positif terhadap tingkat bagi hasil mudharabah. Dan hasil penelitian ini tidak sesuai dengan penilitian yang dilakukan oleh Novianti et al. (2015). 


\subsubsection{Pengaruh ROA terhadap TBHM pada BMT Maslahah Se-Kabupaten Situbondo}

Pengaruh Return on Asset (ROA) terhadap tingkat bagi hasil deposito mudharabah menunjukkan hasil bahwa ROA tidak berpengaruh terhadap Tingkat Bagi Hasil Mudharabah pada BMT Maslahah Se-Kabupaten Situbondo ditunjukan dengan nilai thitung lebih kecil dari $t$ tabel $(1,733<2,069)$, artinya bahwa semakin baik return on asset pada BMT Maslahah Se-Kabupaten Situbondo maka tidak ada pengaruhnya pada Tingkat Bagi Hasil Mudharabah pada BMT tersebut.

Pada dasarnya, semakin tinggi keuntungan yang diperoleh BMT yang diinvestasikan pada asetnya maka akan semakin tinggi pendapatan BMT yang juga berakibat pada tingginya bagi hasil mudharabah yang dibagikan, namun pada BMT Maslahah Se-Kabupaten Situbondo ROA tidak memiliki pengaruh yang dikarenakan return atau laba yang diperoleh BMT Maslahah Se-Kabupaten Situbondo tidak hanya bersumber dari pendapatan pengelolaan dana oleh BMT, tetapi juga berasal dari pendapatan usaha lain (Maslahah Trans, Minimarket Basmalah, Perusahaan Roti), pendapatan imbalaan investasi terikat (terdapat keterikatan anggota saham diseluruh indonesia), serta pendapatan non usaha (aset bank atau koperasi yang merupakan jaminan dari nasabah yang memiliki kredit macet) seperti penjualan aset atau biaya sewa aset.

Hasil penelitian ini menolak hasil penelitian yang dilakukan oleh Siti Rahayu (2015) yang menunjukan bahwa ROA berpengaruh positif terhadap tingkat bagi hasil mudharabah. Dan hasil penelitian ini sesuai dengan penelitian Novianti et al. (2015) yang membuktikan bahwa ROA berpengaruh positif terhadap tingkat bagi hasil deposito mudharabah.

\subsubsection{Pengaruh CAR terhadap TBHM pada BMT Maslahah Se-Kabupaten Situbondo}

Pengaruh Capital Adequacy Ratio (CAR) tehadap Tingkat bagi hasil deposito mudharabah menunjukkan hasil bahwa berpengaruh terhadap Tingkat Bagi Hasil Mudharabah pada BMT Maslahah Se-Kabupaten Situbondo ditunjukan dengan nilai t hitung lebih besar dari t tabel (-2,297>2,069), artinya bahwa semakin baik capital adequancy ratio pada BMT Maslahah Se-Kabupaten Situbondo maka Tingkat Bagi Hasil Mudharabah pada BMT tersebut akan mengalami penurunan.Hal ini dikarenakan kemampuan BMT dalam hal kecukupan modal yang harus disediakan untuk menjamin dana pihak ketiga menjadikan BMT harus berhati-hati dalam memberikan dana mudharabah nya, hal ini bertujuan agar kemampuan BMT membayar kepada pihak ketiga menjadi terjamin dan meminimal risiko tidak mampunya BMT mengembalikan dana tersebut.

Disisi lain Capital Adequacy Ratio (CAR) bank yang tinggi juga dapat mengurangi kemampuan bank dalam melakukan ekspansi usahanya karena semakin besarnya cadangan modal yang digunakan untuk menutupi risiko kerugian. Terhambatnya ekspansi usaha akibat tingginya capital adequacy ratio (CAR) yang pada akhirnya akan mempengaruhi kinerja keuangan bank tersebut sehingga menjadikan tingkat bagi hasil mudharabah yang kecil.

Hasil penelitian ini sejalan dengan penelitian yang dilakukan oleh Rahayu (2015) yang menunjukan CAR berpengaruh negatif terhadap tingkat bagi hasil mudharabah. 


\subsubsection{Pengaruh NPF terhadap TBHM pada BMT Maslahah Se-Kabupaten Situbondo}

Pengaruh Net Performing Finance (NPF) terhadap Tingkat bagi hasil deposito mudharabah menunjukkan hasil bahwa NPF berpengaruh terhadap Tingkat Bagi Hasil Mudharabah pada BMT Maslahah Se-Kabupaten Situbondo ditunjukan dengan nilai t hitung lebih besar dari t tabel $(-2,261>2,069)$, artinya bahwa semakin baik net performing financepada BMT Maslahah Se-Kabupaten Situbondo maka Tingkat Bagi Hasil Mudharabah pada BMT tersebut akan mengalami penurunan.Hal ini dikarenakan NPF menunjukan tingkat risiko kreidt yang dihadapi oleh BMT, semakin tinggi risiko yang dimiliki maka kinerja dari BMT tersebut dikatakan semakin tidak baik yang berdampak pada rendahnya bagi hasil yang dilakukan BMT.

NPF yang tinggi menunjukan bahwa anggota BMT tidak sanggup membayar sebagian atau selutuh kewajibannya pada BMT Maslahah Se-Kabupaten Situbondo.NPF yang tinggi tersebut merupakan sumber kerugian bagi BMT sehingg perlu penangan yang sistematis dan berkelanjutan guna mengurangi dan mencegar tingginya NPF.Tingginya resiko NPF membuat BMT membentuk pencadangan atas kredit bermaslah lebih besar halini menjadikan turunnya pendapatan BMT yang menjadikan kecilnya tingkat bagi hasil mudharabah BMT.

Hasil penelitian ini sejalan dengan penelitian yang dilakukan oleh Novianti et al. (2015) yang membuktikan NPF berpengaruh negatif signfikan terhadap Tingkat Bagi Hasil Mudharabah.

\subsubsection{Pengaruh BOPO terhadap TBHM pada BMT Maslahah Se-Kabupaten Situbondo \\ Pengaruh Biaya Operasional Pendapatan Operasional (BOPO) tehadap Tingkat} bagi hasil deposito mudharabah menunjukkan hasil bahwa berpengaruh terhadap Tingkat Bagi Hasil Mudharabah pada BMT Maslahah Se-Kabupaten Situbondo ditunjukan dengan nilai t hitung lebih besar dari t tabel $(-2,660>2,069)$, artinya bahwa semakin baik beban operasional terhadap pendapatan operasionalpada BMT Maslahah Se-Kabupaten Situbondo maka Tingkat Bagi Hasil Mudharabah pada BMT tersebut akan mengalami penurunan.Hal tersebut menjelaskan bahwa biaya operasional yang tinggi akan memperlihatkan porsi yang tidak seimbang antara pendapatan operasional dengan biaya operasional sehingga akan menimbulkan efek buruk bagi kesehatan BMT yang secara tidak langsung juga berdampak buruk pada tingkat bagi hasil.

Tingkat BOPO yang semakin kecil pada BMT Maslahah Se-Kabupaten Situbondo menunjukan kinerja keuangan yang semakin baik.Biaya operasional yang tinggi justru memperlihatkan porsi yang tidak seimbang antara pendapatan dengan biaya operarasional yang menunjukan kurang baiknya keuangan BMT.Keuangan yang kurang baik menunjukan pendapatan yang rendah diterima oleh BMT sehingga untuk menentukan tingkat bagi hasil mudharabahnya juga mengalami penurunan.

Hasil penelitian ini sejalan dengan penelitian yang dilakukan oleh Novianti et al. (2015) yang membuktikan bahwa BOPO berpengaruh negatif terhadap tingkat bagi hasil mudharabah. 


\subsubsection{Pengaruh Laba Operasional terhadap TBHM pada BMT Maslahah Se- Kabupaten Situbondo}

Pengaruh Laba Operasional berpengaruh terhadap Tingkat Bagi Hasil Mudharabah pada BMT Maslahah Se-Kabupaten Situbondo ditunjukan dengan nilai t hitung lebih besar dari t tabel $(3,874>2,069)$, artinya bahwa semakin baik Laba Operasional pada BMT Maslahah Se-Kabupaten Situbondo maka Tingkat Bagi Hasil Mudharabah pada BMT tersebut akan mengalami peningkatan. Laba Operasional merupakan kelebihan total pendapatan dibandingkan total bebannya, disebut juga pendapatan bersih atau net earnings.

Laba Operasional, yaitu kelebihan total pendapatan dibandingkan total bebanya. Disebut juga sebagai pendapatan bersih atau net earnings (Horngren et al. 2002). Jika pada Laba Operasional ini semakin besar, maka pendapatan bank akan meningkat sehingga bagi hasil yang diterima oleh nasabah juga akan semakin tinggi.

Hasil penelitian ini sesuai dengan penelitian yang dilakukan oleh Volta Hasil penelitian dari Umiyati dan Syarif (2016) hal tersebut berpengaruh terhadap tingkat bagi hasil deposito mudharabah.

\section{KESIMPULAN DAN SARAN}

Berdasarkan hasil analisis terhadap variabel FDR $\left(\mathrm{X}_{1}\right)$, ROA $\left(\mathrm{X}_{2}\right)$, CAR $\left(\mathrm{X}_{3}\right)$, NPF $\left(\mathrm{X}_{4}\right)$, BOPO $\left(\mathrm{X}_{5}\right)$, dan Laba Operasional $\left(\mathrm{X}_{6}\right)$ terhadap TBHM $(\mathrm{Y})$ pada BMT Maslahah Se-Kabupaten Situbondo maka diperoleh kesimpulan sebagai berikut:

a. FDR berpengaruh positif terhadap TBHM pada BMT Maslahah Se-Kabupaten Situbondo, hal ini mengindikasikan bahwa semakin tinggi tingkat financing deposit ratio maka tingkat bagi hasil mudharabah pada BMT Maslahah SeKabupaten Situbondo akan mengalami peningkatan, begitupula sebaliknya semakin rendah financing deposite ratio maka tingkat bagi hasil mudharabah pada BMT Maslahah Se-Kabupaten Situbondo akan mengalami penurunan.

b. ROA tidak berpengaruh positif terhadap TBHM pada BMT Maslahah SeKabupaten Situbondo, hal ini mengindikasikan bahwa semakin tinggi tingkat return on assetmaka tingkat bagi hasil mudharabah pada BMT Maslahah SeKabupaten Situbondo tidak akan mengalami perubahan, begitupula sebaliknya semakin rendah return on assets maka tingkat bagi hasil mudharabah pada BMT Maslahah Se-Kabupaten Situbondo juga tidak akan mengalami perubahan.

c. CAR berpengaruh negatif terhadap TBHM pada BMT Maslahah Se-Kabupaten Situbondo, hal ini mengindikasikan bahwa semakin tinggi tingkat capital adequacy ratio maka tingkat bagi hasil mudharabah pada BMT Maslahah SeKabupaten Situbondo akan mengalami penurunan, begitupula sebaliknya semakin rendah capital adequacy ratio maka tingkat bagi hasil mudharabah pada BMT Maslahah Se-Kabupaten Situbondo akan mengalami peningkatan.

d. NPF berpengaruh negatif terhadap TBHM pada BMT Maslahah Se-Kabupaten Situbondo, hal ini mengindikasikan bahwa semakin tinggi tingkat net performing financing maka tingkat bagi hasil mudharabah pada BMT Maslahah Se-Kabupaten Situbondo akan mengalami penurunan, begitupula sebaliknya semakin rendah net performing financing maka tingkat bagi hasil mudharabah pada BMT Maslahah Se-Kabupaten Situbondo akan mengalami peningkatan.

e. BOPO berpengaruh negatif terhadap TBHM pada BMT Maslahah Se-Kabupaten Situbondo, hal ini mengindikasikan bahwa semakin tinggi tingkat beban operasional terhadap pendapatan operasionalmaka tingkat bagi hasil mudharabah 
pada BMT Maslahah Se-Kabupaten Situbondo akan mengalami penurunan, begitupula sebaliknya semakin rendah beban operasional terhadap pendapatan operasionalmaka tingkat bagi hasil mudharabah pada BMT Maslahah SeKabupaten Situbondo akan mengalami peningkatan.

f. Laba Operasional berpengaruh positif terhadap TBHM pada BMT Maslahah SeKabupaten Situbondo, hal ini mengindikasikan bahwa semakin tinggi tingkat Laba Operasional maka tingkat bagi hasil mudharabah pada BMT Maslahah SeKabupaten Situbondo akan mengalami peningkatan, begitupula sebaliknya semakin rendah Laba Operasional maka tingkat bagi hasil mudharabah pada BMT Maslahah Se-Kabupaten Situbondo akan mengalami penurunan

Berdasarkan hasil analisis data serta pembahasan yang telah dijabarkan maka adapun saran yang diberikan antara lain yaitu

a. Bagi Perusahaan yaitu seluruh BMT Maslahah Se-Kabupaten Situbondo sebaiknya memperbaiki kinerja keuangan perusahaan karena terlihat bahwa kinerja masih dikatakan kurang baik ditunjukan dengan tingginya rasio kredit yang tinggi, hal tersebut menjadikan turunnya minat masyarakat untuk melakukan pinjaman atau menyimpan uangnya karena menganggap sedikitnya bagi hasil yang diperoleh nasabah.

b. Bagi Peneliti Selanjutnya sebaiknya menggunakan perusahaan lain seperti bank syariah atau BMT Sidogiri untuk menjadi pembanding dengan hasil penelitian ini guna mengetahui kinerja yang lebih baik diantara perusahaan atau BMT tersebut. Peneliti selanjutnya juga dapat menggunakan variabel lain guna memperluas faktor yang mungkin menjadi penilaian nasabah dalam menghitung atau memprediksi tingkat bagi hasil yang diperoleh pada lembaga keuangan syariah.

\section{DAFTAR PUSTAKA}

Adnan, M. A. 2005. Akuntansi Syariah: Arah, prospek dan tantangannya: Universitas Islam Indonesia (UII) Press.

Algifari. 2003. Statistika Induktif Untuk Ekonomi dan Bisnis. Yogyakarta: Unit Penerbit dan Percetakan Akadaemi Manajemen Persahaan YKPN.

Chalifah, E., dan A. Sodiq. 2015. Pengaruh Pendapatan Mudharabah dan Musyarakah Terhadap Profitabilitas (ROA) Bank Syariah Mandiri Periode 2006-2014. Jurnal Ekonomi Syariah 3 (1):28-47.

Diyanto, V., dan E. Savitri. 2015. Faktor-faktor yang Mempengaruhi Pertumbuhan Deposito Mudharabah Bank Syariah. PEKBIS (Jurnal Pendidikan Ekonomi Dan Bisnis) 7 (3):185-197.

Horngren, C. T., A. Bhimani, S. M. Datar, G. Foster, dan C. T. Horngren. 2002. Management and cost accounting: Financial Times/Prentice Hall Harlow.

IBI. 2014. Memahami bisnis bank syariah: Gramedia Pustaka Utama.

Indriantoro, N., dan B. Supomo. 2009. Metodologi Penelitian Bisnis, edisi 1. Yogyakarta: BPFE.

Khairunnisa, D., dan M. Arief Ramelan Karseno. 2001. Preferensi masyarakat terhadap Bank Syariah:: Studi kasus Bank Muamalat Indonesia dan Bank BNI Syariah, [Yogyakarta]: Universitas Gadjah Mada.

Lukman, D. 2009. Manajemen Perbankan. Jakarta: Ghalia Indonesia. 
Mas'ud, I., E. Setiawan, dan N. C. Yuliarti. 2020. The Effect of Financing Trading, Profit Sharing and Ijarah to Falah in Sharia Banks. Journal of Contemporary Information Technology, Management, and Accounting 1 (1):39-46.

Novianti, N., T. Badina, dan A. Erlangga. 2015. Analisis Pengaruh Return on Asset (ROA), Biaya Operasional Terhadap Pendapatan Operasional (BOPO), Suku Bunga, Financing to Deposits Ratio (FDR) dan Non Performing Financing (NPF) Terhadap Tingkat Bagi Hasil Deposito Mudharabah (Studi Empiris pada Bank Um. Esensi: Jurnal Bisnis dan Manajemen 5 (1).

Rahayu, S. 2015. Pengaruh return on asset, BOPO, suku bunga dan capital adequacy ratio terhadap tingkat bagi hasil deposito mudharabah pada perbankan Syariah. Journal Of Accounting 1 (1).

Sabtatianto, R., dan M. Yusuf. 2018. Pengaruh BOPO, CAR, FDR dan ROA terhadap Tingkat Bagi Hasil Deposito Mudharabah pada Bank Umum Syariah di Indonesia. Ultimaccounting: Jurnal Ilmu Akuntansi 10 (2):169-186.

Taswan. 2010. Manajemen Perbankan. Yogyakarta: UPP STIM YKPN Yogyakarta.

Umiyati, U., dan S. M. Syarif. 2016. Kinerja Keuangan dan Tingkat Bagi Hasil Deposito Mudharabah Pada Bank Umum Syariah di Indonesia. Jurnal Akuntansi dan Keuangan Islam 4 (1):45-66. 